\title{
PHENOTYPIC, GENOTYPIC, MULTIDRUG RESISTANCE GENES AND DISINFECTANT BIOCIDAL EFFECT OF PASTEURELLA MULTOCIDA ISOLATED FROM CHICKENS
}

\author{
SAMAH E. LABAN ${ }^{1}$; KHALIL M.R. ${ }^{2}$; AMIRA A. MOAWAD ${ }^{3}$; NAGWA S. RABIE ${ }^{4}$ and \\ MONA M. SOBHY ${ }^{5}$ \\ ${ }^{1}$ Veterinary Hygiene and Management Dept. Faculty of Veterinary Medicine, Cairo University. \\ ${ }^{2}$ Poultry Dis. Dept. Animal Health Research Inst. Mansoura Branch, ARC. \\ ${ }^{3}$ Microbiology Dept. Animal Health Research Inst. Mansoura Branch, ARC. \\ ${ }^{4}$ Poultry Dis. Dept. Veterinary Unit, NRC, Dokki, Egypt. \\ ${ }^{5}$ Reproductive Diseases Dept. ARRI. ARC.
}

Received: 7 August 2019; Accepted: 21 September 2019

\begin{abstract}
Pasteurella multocida (P. multocida) type A is the etiologic agent of fowl cholera, a highly contagious and fatal disease of chickens. In this study 300 birds were examined for isolation of $P$. multocida. Isolation of $P$. multocida was attempted from the spleen, lung, trachea and bone marrow collected from chickens. The targeted bacteria from the samples were isolated, identified and characterized based on their morphology, Gram staining, cultural \& biochemical characters and confirmed by pathogenicity test and Polymerase Chain Reaction (PCR). Among the examined chicken, 12 (4\%) P. multocida were isolated and identified $(\mathrm{n}=12 / 300)$. The organisms were gram negative, non-spore forming rod, nonmotile, occurring singly or pairs by Gram staining, whereas in Leishman's stain, bipolarity were observed. All the isolates were positive for oxidase and catalase tests, produced indole. In type specific PCR reaction, the organisms were confirmed as $P$. multocida type A. Disinfectant suspension test used to determine the efficacy of three disinfectants on the isolated strain, only gluteraldehyde- QAC combination product could achieve standard log. reduction of P.multocida after 15 minutes.
\end{abstract}

Key word: Pasteurella multocida, Multidrug resistance genes, Chickens, Disinfectant

\section{INTRODUCTION}

Fowl cholera is contagious and economically important disease of poultry (chicken, ducks and geese). It is caused by Gram-negative rods $P$. multocida which inhabit the upper respiratory tract of many avian species as commensals and cause a severe disease (Rhoades \& Rimler, 1989 and Rimler \& Glisson, 1997). It usually occurs as primary disease that requires predisposing, factors but the factors may increase the severity of the disease (Aye et al., 2001). It may be occurs either as per-acute, acute or chronic forms, and the clinical signs vary depending on the form of the disease. Symptoms include depression, ruffled feathers, fever, and anorexia, mucous discharge from the mouth, diarrhea and an increased respiratory rate (Rhoades \& Rimler, 1989). Carrier birds play a major role in the transmission of fowl cholera (Christensen \& Bisgaard, 2000). Also, research shows that transmission can occur by bird-

Corresponding author: Dr. MONA, M. SOBHY

E-mail address: monagabr17@yahoo.com

Present address: Reproductive Diseases Dept. ARRI. ARC. to-bird contact via aerosolized bacteria as well as through ingestion of bacteria in contaminated environments (Bodenstein et al., 2015).

Five capsular serotypes(A, B, D, E, and F) are usually found in $P$. multocida and each is generally associated with a specific host, for example, Serotype A causes FC in avian species(Harper et al., 2006), serogroup A strains cause the majority of fowl cholera cases (Marza et al., 2015). Virulence of P. multocida varies depending on the strain involved and factors host species (Glisson et al., 2008). The FC is mostly prevalent in winter and late summer (Heddleston and Rhoades, 1978). Laying flocks are mostly affected by FC because of their more susceptibility to the disease as compared with younger chickens (Choudhury et al., 1985; Wang et al., 2009).

The disease usually occurs as septicemia with high morbidity and mortality rates or chronic localized indication of the joints and sinuses (Rimler and Glisson, 1997). The infected birds remain carrier up to 9 weeks after infection. It can affect birds at any age, but occurs rarely in commercial poultry of less than 8weeks of age (Rimler et al., 1998). 
The diagnosis of Pasteurellosis by conventional methods is not reliable and time consuming (Berge et al., 2006; Bell, 2008; Rajeev et al., 2006). Therefore, the use of molecular techniques, specially the polymerase chain reaction (PCR) for molecular detection and characterization of the capsular antigens of the Pasteurella is very important for rapid and specific detection and characterization of the organism which play an important role in the control of the disease among the farms and reducing the economic losses (Rajeev et al., 2006).

Indiscriminate use of anti-biotic resulted in the emergence of multidrug resistant strains of Pasteurella (Rimler \&Glisson, 1997). Fowl cholera is one of important bacterial diseases representing a major threat to the poultry industry (OIE, 2008). Effective cleaning and disinfection of poultry facilities is an important step to reduce microbial loads in the poultry farm environment, equipment and surfaces to break disease cycles. $P$. multocida is an example of pathogenic environmental bacteria that can survive for long periods under various conditions in the environment and act as a source of infection. (Chima et al., 2011). Many disinfectant classes are present of various modes of action but unfortunately, disinfectants may fail to achieve the purpose for which they are used (Onah, 2004). So, disinfectant choice must depend on data about efficacy against the target pathogen and the conditions under which they will be used in the field, such as contact time, organic matter and water hardness (Thomson et al., 2007). Disinfectant efficacy is often tested against laboratory bacterial suspensions to detect their efficacy against specific pathogens in presence of interfering substances like organic matter and hard water (Bloomfield et al., 1991).

Therefore, the present study aims were; isolation, identification, detection of antimicrobial sensitivity of P.multocida isolated from poultry and evaluating the efficacy of some disinfectants commonly used for poultry farm disinfection against the field isolated $P$. multocida under conditions simulating field application.

\section{MATERIALS AND METHODS}

A total of 300 chickens were collected as dead, affected and apparently healthy from different farms in Dakahlia province and examined for presence of Pasteurella multocida. Samples were immediately transferred to the laboratory in sterile plastic bags.

\section{Isolation and identification of Pasteurella multocida:}

Samples (heart blood \& tissue pieces from spleen, liver, lung and bone marrow) were inoculated onto blood agar supplemented with $7 \%$ sheep blood. The plates were incubated for $24-48 \mathrm{hrs}$. at $37{ }^{\circ} \mathrm{C}$. The agar plates were checked every day for suspected colonies. Identification or confirmation of isolated bacterial species was assessed by observation of the colonial morphology, Gram staining and biochemical tests which included catalase, nitrate reduction, $\mathrm{H}_{2} \mathrm{~S}$ production in triple sugar iron (TSI), growth on MacConky`s agar, indol production, urease activity, methyl red production, Voges Proskauer test reaction, oxidase reaction, coagulase, motility, citrate, carbohydrate fermentation from glucose, trehalose, xylose, arabinose, fructose, galactose, maltose, mannose, sucrose, lactose, dulcitol, inocitol, salicin (Quinn et al., 1994). Heart blood smears and tissue impression smears were prepared and subjected to Leishman's staining.

\section{Pathogenicity test:}

The pure cultures of P.multocida isolates in the present study were subjected to pathogenicity studies. One hundred microliter of broth culture were injected intraperitoneal in mice (16 -20g weight) and observed for $48 \mathrm{hrs}$. dead one were subjected to P.M. Examination and reisolution of P.multocida by streaking onto blood agar and incubated at $37^{\circ} \mathrm{C}$ for 24hrs impression smears from heart blood, liver, spleen and lung from dead mice were stained with Leishmans stain and examined for bipolarity. Each isolate was frozen at $-80{ }^{\circ} \mathrm{C}$ in a nutrient broth with $10 \%$ of glycerol for further analysis.

\section{P.multocida species specific PCR (PM-PCR):}

The PCR of P.multocida (PM-PCR) analysis was performed according to Townsend et al. (1998) and the instructor manual provided with kits (Qiagen) with some modification. A PCR reaction mixture (20 $\mu$ total volume) was prepared as follows: $3 \mu$ nuclease free water, $10 \mu$ Hot Start Taq plus master mix (2 xs), $2 \mu$ Coral Load concentrate (10 xs optional), $1 \mu$ forward species specific primer KMT1T7 (5'-ATCCGCTATTTACCCAGTGG-3'), $1 \mu$ reverse primer KMT1SP6 (5'GCTGTAAACGAACTCGCCAC-3') and $3 \mu$ Extracted DNA. The PCR reaction mixture and the thermal cycle protocol were as follows. Initial denaturation at $94^{\circ} \mathrm{C}$ for $5 \mathrm{~min}$, followed by 30 cycles, each cycle consisting of 3 steps- denaturation at $95^{\circ} \mathrm{C}$ for $1 \mathrm{~min}$, annealing at $55^{\circ} \mathrm{C}$ for $1 \mathrm{~min}$, Extension at $72^{\circ} \mathrm{C}$ for $1 \mathrm{~min}$. Final Extension was carried out at $72^{\circ} \mathrm{C}$ for $9 \mathrm{~min}$. Then, the PCR products were visualized by agarose gel electrophoresis.

\section{Capsular PCR typing:}

The P.multocida capsular serogroup specific primers designed by Townsend et al. (2001) were used for capsular PCR typing. The serogroup specific primers hya $\mathrm{D}$ and hya $\mathrm{C}$ were used to amplify capsule biosynthetic loci of serogroup "A" The thermal cycle protocol was as follows. Initial denaturation at $95^{\circ} \mathrm{C}$ for $5 \mathrm{~min}$, followed by 30 cycles, each cycle consisting of 3 steps- denaturation at $95^{\circ} \mathrm{C}$ for $30 \mathrm{sec}$, annealing at $49^{\circ} \mathrm{C}$ for $30 \mathrm{sec}$, Extension at $72^{\circ} \mathrm{C}$ for 80 
sec. Final Extension was carried out at $72^{\circ} \mathrm{C}$ for $5 \mathrm{~min}$ (Sambrook et al., 1989)

\section{Antibiotic sensitivity:}

The antibiotic sensitivity test of the isolated P.multocida in vitro was conducted on Muller-Hinton agar plates according to (Bauer et al., 1966) using 15 antibiotic discs (Ciprofloxacin, Enrofloxacin, Ofloxacin, Oxytetracycline, Doxycycline, Trimethoprim, Ampicillin, Penicillin, Chloramphenicol, Gentamycin, Amikain, Erythromycin, Triple sulpha and Polymyxin as supplied by $\mathrm{M} / \mathrm{s}$. Hi- Media Laboratory, and the antibiotic sensitivity plates were incubated at $37^{\circ} \mathrm{c}$ for 24-48 h.

\section{Disinfectant suspension test:}

Test disinfectants:

Three commercial disinfectants were selected for determination of their efficacy against the isolated $P$. multocida for 5- and 15-minutes contact times. Disinfectants were diluted according to manufacturer recommended concentrations. All dilutions were freshly prepared on the day of the test, using sterilized standardized 400 ppm hard water.

Table 1: Disinfectants used in quantitative suspension test.

\begin{tabular}{cccc}
\hline Disinfectant & Used concentration & Composition & Manufacture \\
\hline Virukill $^{\circledR}$ & $0.5 \%$ & $\begin{array}{c}\text { Potassium peroxymonosulfate 50\%, } \\
\text { NaCL 3\% }\end{array}$ & $\begin{array}{c}\text { UBM } \\
\text { (Egypt) }\end{array}$ \\
\hline Pi Quat 20 & $1: 200$ & $\begin{array}{c}\text { 20\% dual chain quaternary ammonium } \\
\text { compound }\end{array}$ & $\begin{array}{c}\text { Neogen } \\
\text { (USA /Canada) }\end{array}$ \\
\hline Synergize $^{\circledR}$ & $1: 256$ & $\begin{array}{c}\text { Alkyl dimethyl benzyl ammonium } \\
\text { chloride 26\% and Gluteraldehyde 7\% }\end{array}$ & $\begin{array}{c}\text { Neogen } \\
\text { (USA /Canada) }\end{array}$ \\
\hline
\end{tabular}

Laboratory suspension test according to PrEN1276 CEN (2004) was used with some modifications to evaluate the efficacy of test disinfectants on the isolated P.multocida strain. In brief; $1 \mathrm{ml}$ of the bacterial suspension adjusted to approximately $10^{8} \mathrm{cfu}$. $/ \mathrm{ml}$ using McFarland standard was added to $1 \mathrm{ml}$ of yeast extract $5 \%$ sterile solution as a source of organic matter. The mixture was left for $2 \mathrm{~min}$. after that $8 \mathrm{ml}$ of the diluted test disinfectant added and the mixture maintained for 5 and 15 minutes. After the previously given contact times $1 \mathrm{ml}$ of the mixture was received into a tube containing $8 \mathrm{ml}$ of the neutralizing solution (polysorbate $80(30 \mathrm{~g} / \mathrm{L}$, lecithin $3 \mathrm{~g} / \mathrm{L}$, sodium thiosulphate $5 \mathrm{~g} / \mathrm{L}$, L-histidine $1 \mathrm{~g} / \mathrm{L}$ and saponin $30 \mathrm{~g} / \mathrm{L}$ ) dissolved in Tryptone Soya Broth and $1 \mathrm{ml}$ of water to stop the disinfectant activity. Tubes then were mixed and left for neutralization for 5minutes. Following neutralization, viable bacterial counts were determined by spread plating of serially diluted samples in duplicates with plates incubated at $37{ }^{\circ} \mathrm{C}$ for 24 hours. The test compound was effective against the organism at the stated dilution if it achieved five $\log$ reductions in viable counts.

\section{RESULTS}

The collected samples revealed positive isolation of 12 strains (4\%) of P. multocida isolated from lung, spleen and trachea of birds as shown in tables. No growth was observed on Mac Conky agar, Gram staining show gram negative coccobacillus and on Leishman`s revealed characteristic bipolar organism suggestive of P.multocida.

Table 2: Occurrence of $P$. multocida in birds.

\begin{tabular}{|c|c|c|c|c|}
\hline \multicolumn{2}{|c|}{ Status of birds } & No. of samples & $\begin{array}{c}\text { Occurrence of } \\
\text { P.multocida }\end{array}$ & $\%$ \\
\hline \multirow{2}{*}{ Diseased } & Layers (3-12month & 150 & 9 & 6 \\
\hline & Broiler (6-8 week ) & 50 & 1 & 2 \\
\hline \multirow{3}{*}{ Apparently healthy } & Layers (3-12month ) & 70 & 2 & 2.8 \\
\hline & Broiler (6-8 week ) & 30 & -- & $\mathbf{0}$ \\
\hline & Total & 300 & 12 & 4 \\
\hline
\end{tabular}


Table 3: Occurrence of $P$. multocida in diseased and apparently healthy chickens.

\begin{tabular}{ccccc}
\hline \multirow{2}{*}{ Tissue } & \multicolumn{5}{c}{ Number of P. multocida } \\
\cline { 2 - 5 } & \multicolumn{2}{c}{ Diseased } & \multicolumn{2}{c}{ Apparently healthy } \\
\cline { 2 - 5 } & broiler & layer & broiler & Layer \\
\hline Bone marrow & & $\mathbf{2}$ & - & $\mathbf{1}$ \\
\hline Lung & $\mathbf{1}$ & $\mathbf{2}$ & - \\
\hline Trachea & $\mathbf{2}$ & $\mathbf{2}$ & $\mathbf{1}$ \\
\hline Spleen & & $\mathbf{1}$ & - & $\mathbf{2}$ \\
\hline Total & & $\mathbf{1 0}$ & &
\end{tabular}

Table 4: Seasonal variation of $P$. multocida in tissues of diseased and apparently healthy chickens.

\begin{tabular}{cccc}
\hline Season & Diseased & Apparently healthy \\
\hline Autumn & $\mathbf{2}$ & - \\
\hline Summer & $\mathbf{1}$ & $\mathbf{2}$ \\
\hline Winter & $\mathbf{5}$ & - \\
\hline Spring & $\mathbf{2}$ & $\mathbf{2}$ \\
\hline Total & $\mathbf{1 0}$ & \\
\hline
\end{tabular}

All isolates subjected to mice inoculation test killed the mice within 24 to $48 \mathrm{~h}$. post inoculation. On Leishman's staining, Heart blood smears, tissue impression smears prepared from liver, spleen and lung revealed characteristic bipolar organisms suggestive of $P$. multocida.
PCR has been proved to be useful in the detection of DNA of P.multocida. P.multocida species specific PCR (PM-PCR) was used in this study to identify P.multocida isolates. The molecular weight of the PCR products of all isolates were found to be $460 \mathrm{bp}$ specific for P.multocida.

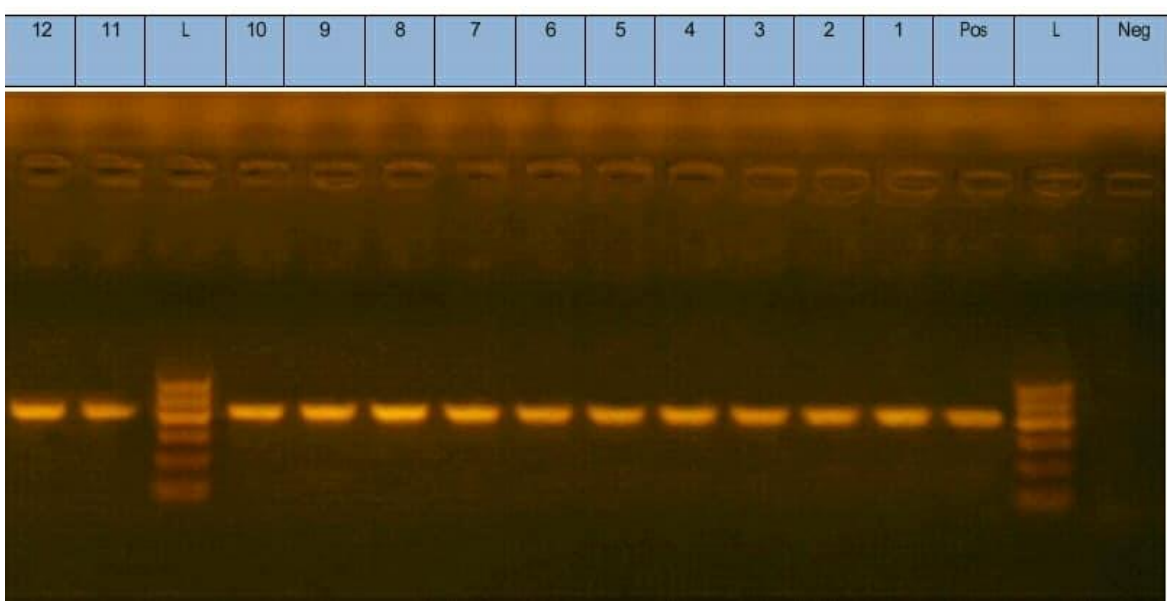

Agarose gel electrophoresis showing amplification of $460 \mathrm{bp}$ fragments specific for $P$. multocida field isolates.

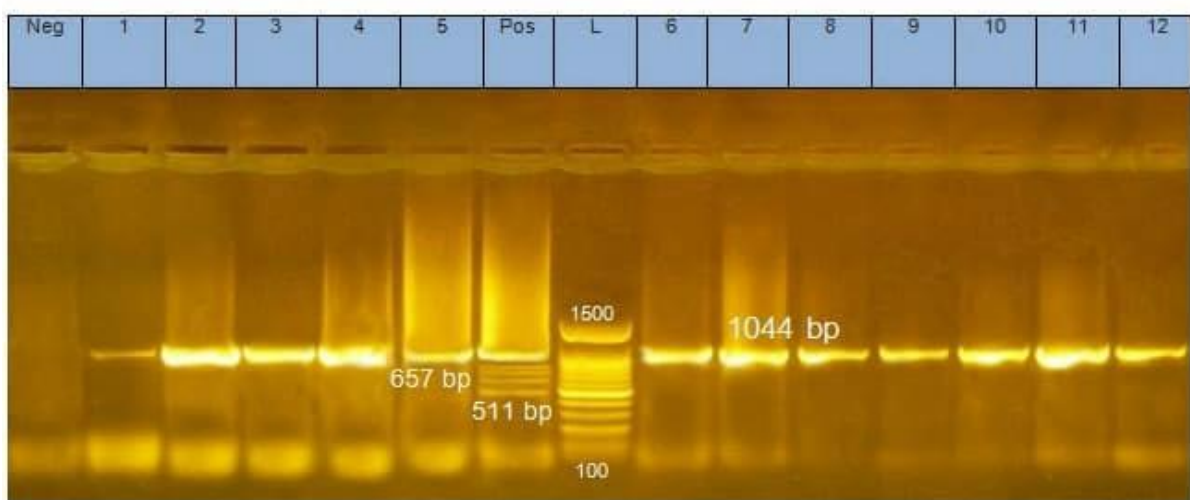

Agarose gel electrophoresis showing amplification of $1044 \mathrm{bp}$ fragments specific to the capsular antigen type A. 


\section{Results of phenotypic antibiotic susceptibility testing}

P.multocida were multidrug resistant in which antibiotic sensitivity tests revealed that all the isolates were resistant to gentamycin, ampicillin, erythromycin, penicillin, tobramycin, chloramphenicol, doxycycline, cephotaxime, colistin
(100\%) followed by apramycin and ciprofloxacin $(83.33 \%)$ then, tetracycline, amoxicillin, clavulenic acid $(66.7 \%)$ vancomycin and neomycin $(50 \%)$ and ofloxacin $(16.6 \%)$.

\section{Results of disinfectant quantitative suspension} test:

Table 5: $\log$ reductions of P.multocida disinfectant suspension test after 5 and $15 \mathrm{~min}$.

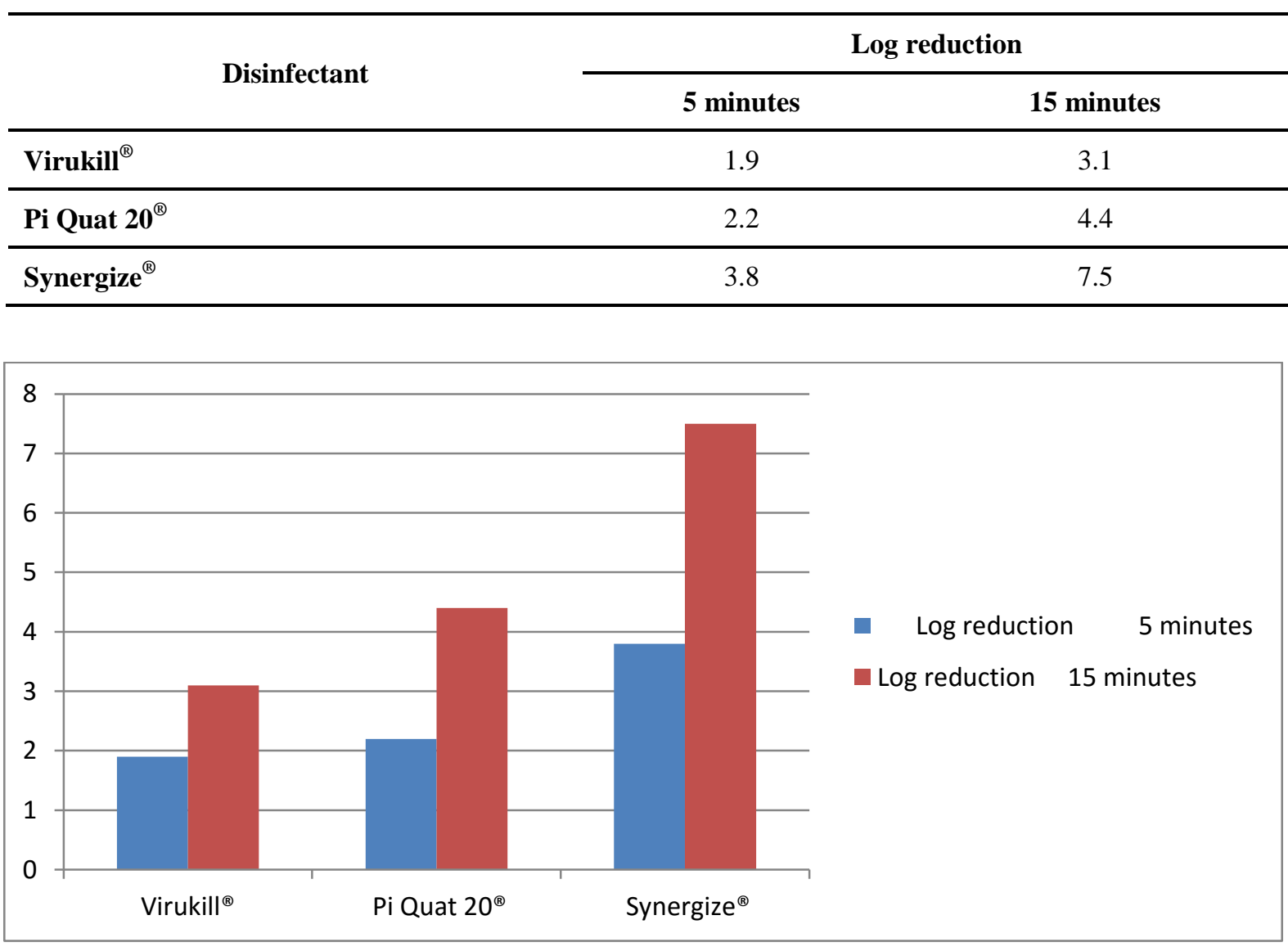

Fig. (1): Reductions of disinfectant suspension test after 5 and 15 minutes.

\section{DISCUSSION}

In the present investigation, as shown in tables, 12 isolates of P.multocida were isolated out of a total 300 samples with an isolation rate $4 \%$. All the isolates showed typical cultural characteristics of dew drop, mucoid, non-hemolytic on blood agar, Gram negative coccobacillary by gram staining and Leishman's stain revealed characteristic bipolarity organism. These findings are in accordance with Quinn (1994) and OIE (2004). The isolates subjected to biochemical tests were positive for indol production ,nitrate reduction, oxidase and catalase production these findings were in agreement with several other studies (Shivachandra et al., 2005; Ashraf et al., 2011; Manasa, 2012; Ievy et al., 2013; Akhtar, 2013). These results agree with those obtained by Kwage et al. (2013) who found that out of 512 poultry were cultured at necropsy for the organism from the liver, spleen, lungs and heart blood only $6(1.2 \%)$ were positive for $P$. multocida. Also Mohamad et al. (2012) who revealed that a total of 21 isolates P.multocida were recovered in 21 out of 275 backyard chickens from different regions of Upper Egypt tested (7.6\%) and were confirmed using phenotypic characterization.

The prevalence of P.multocida $(4 \% ; n=12 / 300)$ in this study was lower than the value reported in the earlier studies Hassan et al. (2010) reported $12.05 \%$ prevalence in layer chicken and $4.25 \%$ in broiler chicken, whereas Hossain et al. (2013) found 13.04\% prevalence in chicken and Belal (2013) found 59.72\% in backyard poultry. All the isolates subjected to mice inoculation tests killed the mice in $24-48 \mathrm{~h}$. These results are in agreement with the findings of Kumar (1998) and Balakrishnan and Mini (2001). 
PCR technology can be applied for rapid, sensitive and specific detection of $P$. multocida Townsend et al. (1998) and OIE (2008). The 12 isolates showed corresponding amplicons of 460 base pairs which is specific for $P$. multocida this result was in agreement with those reported by Townsend et al., 2001, Kumar et al., 2009, Ranjan et al., 2011, Manasa, 2012, and Akhtar, 2013). It was noticed that there was homogeneity in the distinct banding patterns of all the $12 P$. multocida isolates that were amplified.

The findings of this work showed that all the 12 isolates of $P$. multocida gave a uniform amplicons size corresponding to 1,044 base pairs indicating that they all belong to capsular group A. Similar results have been observed by Chung et al. (2001) and Jaglic et al. (2005). This report has lent credence to the reports of Glisson et al. (2003) and Kumar et al. (2004) who reported that fowl cholera is mainly caused by $P$. multocida belonging to capsular group A. Also Jabbari et al. (2003) stated that all P.multocida isolates identified as capsular type A. The present finding differs from reports of Kumar $e t$ al. (1996) and Chawak et al. (2000) who documented that fowl cholera in avian species, such as chickens, ducks, turkeys, quails, geese, pigeons and cage birds are caused by capsular group D:3 and F:3.

P.multocida were multidrug resistant in which antibiotic sensitivity tests revealed that all the isolates were resistant to gentamycin, ampicillin, erythromycin, penicillin, tobramycin, chloramphenicol, doxycycline, cephotaxime and colistin $(100 \%)$ followed by apramycin and ciprofloxacin $(83.33 \%)$ then, tetracycline, amoxicillin and clavulenic acid (66.7) vancomycin and neomycin $(50 \%)$ and ofloxacin $(16.6 \%)$.

Results of disinfectant suspension test revealed that logarithmic reductions of P.multocida required according to the used standard (5 log. reductions)was obtained after exposure to Synergize (gluteraldehydeQAC combination) for 15 minutes as it achieved 7.5 log. reductions. However, it showed resistance to the same product at 5 minutes and to the other two products; Pi- Quat 20(QAC) and Virukill (potassium peroxymonosulfate- $\mathrm{NaCl}$ combination) after 5 or 15 minutes. Researchers recommended evaluation of disinfectants using locally isolated strains rather than laboratory ATCC strains due to the possibility of development of bacterial resistance following exposure to environmental factors or frequent disinfectant application particularly of quaternary ammonium compounds (Langsrud et al., 2003, Chima et al., 2012). In a study applied by In-Soo et al. (2014) the environmentally isolated P.multocida showed higher disinfectant resistance than ATCC strains. According to CDC, (2008), gluteraldehydebased disinfectants are characterized by excellent biocidal properties even in presence of high organic matter. However, QACs potency impaired by hardness and gram-negative bacteria can survive or grow in them. Thomson et al. (2007) found that Gluteraldehyde plus quaternary ammonium1:50 1:190 and Quaternary ammonium 1:50-1:100 showed efficacy against P.multocida under low organic matter conditions. In a study applied on Pseudomonas aeruginosa, Escherichia coli and Salmonella typhimurium obtained from commercial poultry facilities using qualitative suspension test, the selected bacteria were resistant to QAC and virkon-s after 10 minutes. However, Gluteraldehyde + QAC achieved high level of antimicrobial activity even in the presence of organic matter (Gehan et al., 2009). In another study Yan-Lin et al. (2008) stated that potassium monopersulfate $1250 \mathrm{mg} / \mathrm{L}$ for $2.5 \mathrm{~min}$ could achieve 5 logs. reductions of $P$. multocida. Sonthipet et al. (2018) examined the efficacy of potassium monopersulfate on E. coli and S. infantis in presence and absence of 5\% FBS. Results showed that $312.5 \mathrm{ppm}$, in presence of organic materials could not inactivate E. coli within $15 \mathrm{~min}$. and 625 and $312.5 \mathrm{ppm}$, could not inactivate $\mathrm{S}$. infantis. Ruano et al. (2001) concluded the need of most microbial to increased contact times with the disinfectant or higher concentration.

\section{CONCLUSION}

Twelve isolates of $P$. multocida were isolated from filed cases of fowl cholera of chicken. In addition to conventional methods such as staining, cultural and biochemical test, identification of the isolated organisms as $P$. multocida was confirmed by molecular approach i.e., PCR using the primers specific for $P$. multocida. Antibiotic susceptibility was applied using isolated P.multocida for detection of most effective antibiotics. Disinfectant quantitative suspension test was applied against the isolated $P$. multocida using three disinfectants; Gluteraldehyde-QAC combination product was bactericidal after 15 minutes of contact with recommendations for increasing contact time and concentration.

\section{REFERENCES}

Akhtar, M. (2013): Isolation, identification and characterization of Pasteurella multocida from chicken and development of oil based vaccine, MS thesis, Department of Microbiology and Hygiene, Bangladesh Agricultural University, Mymensingh.

Ashraf, A.; Tariq, H.; Shah, S.; Nadeem, S.; Manzoorl, L.; Ali, S.; ljaz, A. and Gailani, Mehboob, S. (2011): Characterization of Pasteurella multocida strains isolated from cattle and buffaloes in Karachi, Pakistan .African Journal of Microbiology Research, 5; 4673-4677. 
Aye, P.P.; Angrick, E.J.; Morishita, T.Y. and Harr, B.S. (2001): Prevalence and characteristics of P. multocida in commercial turkeys. Avian Dis., 45(1): 182-190.

Balakrishnan, G. and Mini, M. (2001): Plasmid profile and antibiotic resistance pattern of $\mathrm{P}$. multocida of avian origin. Indian Vet. J., 78: 783-786.

Bauer, A.W.; Kirby, W.M.M.; Sherris, J.C and Tutck, M. (1966): Antibiotic susceptibility testing by standardized single disk method. Am. J. Clin. Pathol. 45: 493-503.

Belal, SMSH. (2013): Occurrence of Pasteurellosis and Newcastle disease in indigenous in chicken sirajgonj district. Bangladesh Journal of Veterinary Medicine, 11: 97-105.

Bell, S. (2008): Treatment and control of Respiratory disease. Br. Vet. Assoc. 30 (5): 278-283. InPractice.

Berge, A.C.B.; Sischo, W.M. and Craigmill, A.L. (2006): Antimicrobial susceptibility patterns of respiratory tract pathogens. J. Am. Vet. Med. Assoc. 229(8): 1279-1281.

Bloomfield, S.F.; Arther, M.; Looney, E.; Begun, K. and Patel, H. (1991): Comparative testing of disinfectant and antiseptic products using proposed European suspension testing methods. Lett. Appl. Microbiol. 13: 233-237.

Bodenstein, B.; Beckmen, K.; Sheffield, G.; Kuletz, K.; Van Hemert, C.; Berlowski, B. and Shearn-Bochsler, V. (2015): Avian cholera causes marine bird mortality in the Bering Sea of Alaska. J. Wildl. Dis. 51: 934-937.

CEN (2004): European Committee for Standardization Chemical disinfectants and Antiseptics-Quantitative suspension test for evaluation of bactericidal activity of chemical disinfectants and antiseptics used in food, industrial, domestics, and institutional areasTest method and requirements (Phase 2, Step 1). PrEN 1276: 2004. CNE, Central Secretariat: rue de Stassart 36, 1050 Brussels, Belgium.

CDC (2008): Guideline for Disinfection and Sterilization in Healthcare Facilities. https:// www.cdc.gov/infectioncontrol/pdf/guidelines/ disinfection-guidelines.pdf.

Chawak, M.M.; Verma, K.C.; Kataria, J.M. and Kumar, A.A. (2000): Characterization of indigenous isolates of Pasteurella multocida. Indian Journal of Comparative Microbiology, Immunology and Infectious Diseases, 21: 111114.

Chima, I.U.; Uchegbu, M.C.; Okoli, I.C. and Okoli, C.G. (2011): Survey of chemical disinfectants used by poultry farmers in Imo State, Nigeria. Online J. Anim. Feed Res., 1: 223-230.

Chima, I.U.; Unamba-Opara, I.C.; Ugwu, C.; Udebuani, A.C. and Okoli, C.G. (2012): Biosecurity and disinfection controls of poultry microbial pathogen infections in Nigeria. J. World's Poult. Res., 2: 5-17).

Choudhury, KA.; Amin, MR.; Rahman, A. and Ali, $M R$. (1985): Investigation of natural outbreak of fowl cholera. Bangladesh Veterinary Journal, 19: 49-56.

Christensen, J.P. and Bisgaard, M. (2000): Fowl cholera. Revue Scientifique. ET Technique Office International des Epizooties, 19, 626637.

Chung, J.Y.; Wilkie, I.; Boyce, J.D.; Townsend, K.M.; Frost, A.J.; Ghoddusi, M. and Adler, $B$. (2001): Role of capsule in the pathogenesis of fowl cholera caused by Pasteurella multocida serogroup A. Infection and immunity, 69(4), 2487-2491.

Gehan, Z.M.; Anwer, W.; Amer, H.M.; EL-Sabagh, I.M.; Rezk, A. and Badawy, E.M. (2009): In vitro Efficacy Comparisons of Disinfectants Used in the Commercial Poultry Farms International Journal of Poultry Science 8 (3): 237-241.

Glisson, J.R.; Hofacre, C.L. and Christensen, J.P. (2003): Avian Pasteurellosis. Diseases of Poultry, 11th Ed. Iowa State University Press, Ames, Iowa, USA, Pp. 658-676.

Glisson, J.R.; Hofacre, C.L. and Christensen, J.P. (2008): Fowl cholera. In: Diseases of Poultry, Saif YM, Barnes HJ, Glisson JR, Fadly AM, McDougald LR and Swayne DE (Editors). Blackwell Publishing, Ames, Iowa, USA; pp 739-758.

Harper, M.; Boyce, JD. and Adler, B. (2006): Pasteurella multocida pathogenesis: 125 years after Pasteur. FEMS Microbiology Letters, 265: $1-10$.

Hassan, R.A.K.M.; Ali, M.H.; Siddique, M.P.; Rahman, M.N. and Islam, M.A. (2010): Clinical and laboratory diagnosis of broiler and layer chickens. Bangladesh Veterinary Journal, 8:107-115.

Heddleston, K.L. and Rhoades, K.R. (1978): Avian Pasteurellosis in diseases of poultry. 7th Edn. Iowa State University Press, Ames. Iowa, USA; pp 181-199.

Hossain, M.S.; Akter, S.; Ali, M., Das, P.M. and Hossain, M.M. (2013): Bacteriological and pathological investigation of nasal passage infections of chickens (Gallus gallus). The Agriculturists, 11: 47-55.

Ievy, S.; Khan, M.R.F.; Islam, M.A. and Rahman, M.B. (2013): Isolation and identification of Pasteurella multocida from chicken for the preparation of oil adjuvant vaccine. Bangladesh journal of veterinary medicine, 2 : 1-4.

In-Soo, J.; Hyun-Jung, K.; Won-Yong, J. and ChanWha, K. (2014): Hydrogen Peroxide as an Effective Disinfectant for Pasteurella multocida. Yonsei Med J. 1; 55(4): 11521156. 
Jabbari, M.; Sohrabpour, S. and Eslami, M.R. (2003): General solution for mechanical and thermal stresses in a functionally graded hollow cylinder due to nonaxi symmetric steady-state loads. ASME J Appl Mech, 70 (2003), pp. 111-118

Jaglic, Z.; Kucerova, Z.; Nedbalcover, K.; Pavlik, I.; Alexa, P. and Barbs, M. (2005): Characterization and comparison of Pasteurella multocida isolated from different species in the Czech Republic: Capsular PCR typing, rib typing and dermonecrotoxin production. Veterinary Medicine Czechoslovakia, 50: 345-354.

Kumar, R.A.; Vaze, M.B.; Chandra, N.R.; Vijayan, M. and Muniyappa, K. (1996): Functional characterization of the precursor and spliced forms of RecA protein of Mycobacterium tuberculosis. Biochemistry 35(6): 1793-802

Kumar, A.A.; Shivachandra, S.B.; Biswas, A.; Singh, V.P.; Vijendra, P. and Srivastava, S.K. (2004): Prevalent serotypes of Pasteurella multocida isolated from different animals and avian species in India. Veterinary Research Communication, 28: 657-667.

Kumar, P.; Singh, V.P.; Agrawal, R.K. and Singh, S. (2009): Identification of Pasteurella multocida isolates of ruminant origin using polymerase chain reaction and their Antibiogram study. Tropical Animal Health and Production, 41: 573-578.

Kwage; J.K.P.; Ekundayo; S.O.; Chuku; A.; Yusuf; A.F.; Mwankon; E.S.; Boss; S.S. and Muhammad; M. (2013): Phenotypic and genotypic characterization of Pasteurella multocida isolated from dead poultry in Jos, Plateau State. Nigerian Veterinary Journal, 34 (2).

Langsrud, S.; Singh Sidhu, M.; Heir, E. and Holck, A.L. (2003): Bacterial disinfectant resistance-a challenge for the food industry. Int Biodeter \&Biodegrad 51, 283-290.)

Manasa, YS. (2012): Isolation And Characterization of Pasteurella multocida From cattle In Plateau State, Nigeria PhD Thesis, Department of Veterinary Pathology and Microbiology, Faculty of Veterinary Medicine, Ahmadu Bello University, Zaria, Nigeria.

Marza, AD.; Abdullah, FFJ.; Ahmed, IM.; Chung, ELT.; Ibrahim, HH.; Zamri-Saad, M.; Omar, AR.; Bakar, MZA.; Saharee, AA.; Haron, AW. and Lila, MAM. (2015): Pasteurella multocida B:2 infection: A review of clinic pathological and pathophysiological changes. Journal of Advanced Veterinary and Animal Research, 2: 252-262.

Mohamed, M.W.A. and Mageed, M.A.A. (2012): Molecular analysis of Pasteurella multocida strains isolated from fowl cholera infection in backyard chickens. Asian Pacific journal of tropical biomedicine, 4(1), 8-12.
OIE (2008): Manual of standards for diagnostic test and vaccines, 6th Edn, pp 524-530.

Onah, D.N. (2004): Biosecurity in modern livestock production. Proceedings of the National Workshop on Continuing Education for Veterinary and Livestock Workers, June 2125, 2004, Nsukka, Nigeria

Quinn, P.J.; Markey, B. and Carter, G.R. (1994): Clinical Veterinary Microbiology. Wolfe, Baltimore. pp. 327-344.

Rajeev-Gautam, Dutta T.K.; Kumar, A.A. and Shivachandra, S.B. (2006): Molecular typing of Indian isolates of $P$. multocida serogroup-A from different animal species. Indian J. Anim. Sci. 76(11):867-872.

Ranjan, R.; Panda, S.K.; Acharya, A.P.; Singh, A.P. and Gupt, A. (2011): Molecular diagnosis of Hemorrhagic septicemia. Veterinary World, 4: 189-192.

Rhoades, K.R. and Rimler, R.B. (1989): Fowl cholera. In C. Adlam \& J.M. Rutter (Eds.), Pasteurella and Pasteurellosis (pp. 95_113). London: Academic Press.

Rimler, R.; Calnek, B.W.; Barnes, H.J.; Beard, C.W.; MacDougal, L.R. and Saif, Y.A. (1998): Fowl cholera. In: Diseases Poultry. 10 ${ }^{\text {th }}$ Ed. Ames Iowa State Univ. Press. Pp: 143-159.

Ruano, M.; El-Attrache, J. and Villegas, P. (2001): Efficacy comparisons of disinfectants used by the commercial poultry industry. Av. Dis., 45: 972-977.

Sambrook, E.F.; Fritsch, T. and Maniatis, T. (1989): Molecular cloning: a laboratory manual (2nd Ed.) Cold Spring Harbor Laboratory Press, USA, New York, pp. 54-60.

Shivachandra, SB.; Kumar, AA.; Gautam, R.; Saxena, MK.; Chaudhuri, $P$. and Srivastava, SK. (2005): Detection of multiple strains of P.multocida in fowl cholera outbreaks by polymerase chain reaction-based typing. Avian Pathology, 34: 456-462.

Sonthipet, S.; Ruenphet, Sakchai and Takehara, Kazuaki (2018): Bactericidal and virucidal efficacies of potassium monopersulfate and its application for inactivating avian influenza virus on virus-spiked clothes. J. Vet. Med. Sci.80 (4): 568-573.

Thomson, J.R.; Bell, N.A. and Rafferty, M. (2007): Efficacy of some Disinfectant compounds against porcine bacterial pathogens. Pig Journal.

Townsend, K.M.; Townsend, A.J.; Frost, C.; Lee, J.M.; Papadimitriou, H.J. and Dawkins, S. (1998): Development of PCR assays for species and type-specific identification of Pasteurella multocida isolates J. Clin. Microbiol. pp. 1096-1100.

Townsend, KM.; Boyce, JD.; Chung, JY.; Frost, AJ. and Adler, B. (2001): Genetic organization of Pasteurella multocida cap loci and development of a multiplex capsular PCR 
typing system. Journal of Clinical Microbiology, 39: 924-929.

Wang, C.; Wu, Y.; Xing, X.; Hu, G.; Dai, J. and He, H. (2009): An outbreak of avian cholera in wild waterfowl in Ordos wetland, Inner Mongolia, China. Journal of Wildlife Diseases, 45: 1194-1197.
Yan-Lin, Y.; Hong-Zhong, Y. and Hui, X. (2008): Observation On Germicidal Efficacy Of Compound Potassium Monopersulfate Disinfectant. Chinese Journal of Disinfection, 2008-02.

\section{الخصائص المظهرية والجينية ودرجة مقاومة الباستيريلا مالتوسيدا المعزولة من الاجاج للأدوية وتأثير بعض مضاولة المطهرات عليها مالتوبيا}

\section{سماح لبن ، مصطفى ربيع خليل ، أمبرة أحمد معوض ، نجوى سعد ربيع ، منى مححا صبحى}

E-mail: monagabr17@yahoo.com Assiut University web-site: www.aun.edu.eg

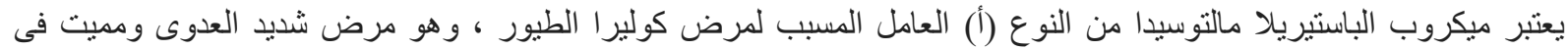

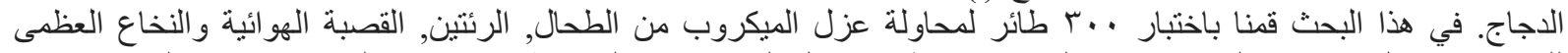

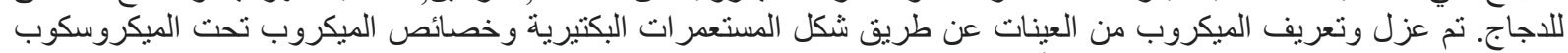

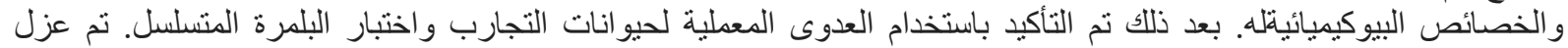

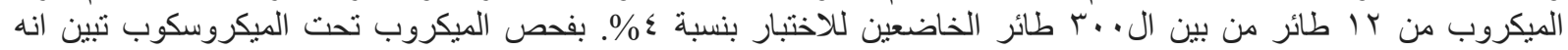

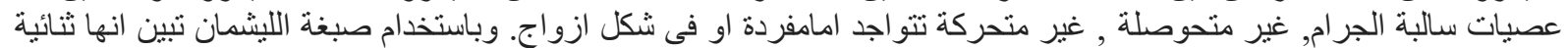

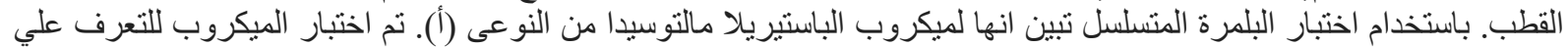

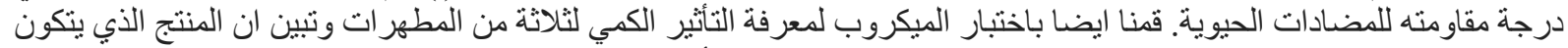
من الجلوتر الدهايد ومركب الامونيا الرباعي هو الذى نمكن من تحقيق التأثير النموذجى المذكور في الاختبار الاصلى بعد مرور 10

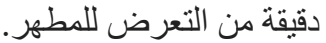

